\title{
Rooting of semihardwood cuttings of cataia collected in four seasons
}

\author{
Enraizamento de estacas semilenhosas de cataia coletadas em quatro estações
}

\author{
Luciele Milani Zem ${ }^{\mathrm{I}}$ Katia Christina Zuffellato-Ribas ${ }^{I I}$ \\ Maria Izabel Radomski ${ }^{\mathrm{II}}$ Henrique Soares Koehler ${ }^{\mathrm{IV}}$
}

\section{- NOTE -}

ABSTRACT

Drymis brasiliensis Miers is a specie of the Winteraceae family, commonly known as cataia or pepper bark. This research was carried out with the aim to study the rooting of semihardwood cuttings, subjected to different concentrations of indolebutyric acid (IBA), collected in four seasons of the year (autumn, winter, spring and summer). Cuttings were prepared with $10-12 \mathrm{~cm}$ length, keeping two halved leaves. Bases of cuttings were treated as follows: control (100\% water), 0; 500; 1500; 3000; 4500 and 6000mg $L^{-1} I B A$. One hundred and twenty after the planting the following variables were assessed: rooting percentage, number of roots per cutting, length of roots per cutting, cutting callus percentage, cuttings with new shoots and number of cuttings that maintained the initial leaves. The indolebutyric acid is not recommended for rooting of Drimys brasiliensis cuttings. The cuttings collected in winter were the ones that showed greatest rooting percentage $(46.96 \%)$ for the production of nursery plant of Drimys brasiliensis.

Key words: Winteraceae, Drimys brasiliensis, indolebutyric acid, vegetative propagation.

\section{RESUMO}

Drimys brasiliensis Miers é uma espécie pertencente à familia Winteraceae, popularmente conhecida como cataia. $O$ trabalho foi realizado com o objetivo de avaliar o enraizamento de estacas semilenhosas, submetidas a diferentes concentrações de ácido indol butírico (AIB), coletadas nas quatro estações do ano (outono, inverno, primavera e verão). As estacas foram preparadas com 10-12cm de comprimento e duas folhas cortadas pela metade na porção apical. As bases das estacas foram submetidas aos tratamentos: testemunha (100\% água), 0, 500, 1500, 3000, 4500 e $6000 \mathrm{mg} \mathrm{L}^{-1}$ AIB. Após 120 dias em casa de vegetação, avaliaram-se a porcentagem de estacas enraizadas, o número de raizes por estaca, o comprimento das três maiores raizes por estaca, a porcentagem de estacas com calos, as estacas com novas brotações e as estacas que mantiveram as folhas iniciais. $O$ ácido indolbutírico não é recomendado para o enraizamento de estacas de Drimys brasiliensis. As estacas coletadas no inverno foram as que apresentaram melhor porcentagem de enraizamento $(46,96 \%)$ para a produção de mudas.

Palavras-chave: Winteraceae, Drimys brasiliensis, ácido indol butírico, propagação vegetativa.

Drymis brasiliensis Miers belongs to the Winteracea family and is commonly known as "cataia" or pepper bark (CRONQUIST, 1981; TRINTA \& SANTOS, 1997). The genus Drymis means spicy in Greek, due to the taste of its aromatic bark, and brasiliensis is referred to its habitat (TRINTA \& SANTOS, 1997).

According to SCHEIDT et al. (2002), species of the genus Drymis are characterized by the use of their bark in the traditional Brazilian medicine as stimulants, antispasmodic, aromatics, antidiarrheal, antipyretic, against uterus hemorrhage and in some affections of the digestive tract (SIMÕES et al., 1986).

It is a tree reaching up to $20 \mathrm{~m}$ in height, typical of humid and cold environments, being tolerant to low temperatures. It's heliophyl, monoicous and perennial, flowering up to twice a year (TRINTA \& SANTOS, 1997). Seeds are reniform, with a brilliant black color and a big quantity of endosperm. They

\footnotetext{
IPrograma de Pós-graduação em Agronomia, Produção Vegetal (PGAPV), Departamento de Fitotecnia, Universidade Federal do Paraná (UFPR), Rua Quintino Bocaiuva, 105, 80035-009, Curitiba, PR, Brasil. E-mail: luzem@uol.com.br. Corresponding author.

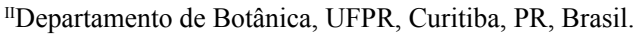

IIIEmbrapa Florestas, Colombo, PR, Brasil.

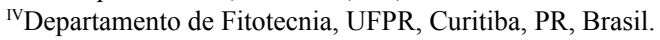


present dormancy, which is a problem for the analysis of seeds and seedlings production. Dormancy is due to embryonal immaturity, since the rudimentary embryos need an additional time period to complete their development before being ready for germination (ABREU et al., 2005).

Due to the difficulty to produce seedlings from seeds, cuttings propagation turns out to be a recommended technique for the production of seedlings in large scale (SANTOS et al., 2010; HARTMANN et al., 2011).

Synthetic plant regulators belonging to the auxins group are substances that help the cuttings to generate roots (SANTOS et al., 2010). They induce an increase in the percentage of rooted cuttings, reduce the time of roots formation and reduce the permanence of cuttings in the rooting bed.

Seasons of the year are also related to viability of roots (NORBERTO et al., 2001), being able to have influence on rooting (FANTI, 2008). For some species with easy rooting cuttings can be collected in any season of the year, however for others, seasons with the highest rooting may correspond to the dormant period, or to the growing period (HARTMANN et al., 2011).

Thus, this research was carried out with the aim to study the propagation of Drimys brasiliensis by rooting of semihard wood cuttings, subjected to different concentrations of indolebutyric acid (IBA), collected in four seasons of the year (autumn, winter, spring and summer).

Vegetative material from Drimys brasiliensis Miers was collected in the woods of Embrapa Florestas in the municipality of Colombo (PR), identified by the geographical coordinates $25^{\circ} 19^{\prime} 16^{\prime \prime}$ S latitude and 49 09'31'W longitude.

The experiment was installed with a factorial arrangement $4 \times 7$, being 4 seasons of the year: April $2^{\text {nd }} 2012$ (autumn), July $2^{\text {nd }} 2012$ (winter), October $3^{\text {rd }} 2012$ (spring) and January $9^{\text {th }} 2013$ (summer) and 7 IBA concentrations: control (100\% water), 0, 500, 1500, 3000, 4500 and $6000 \mathrm{mg} \mathrm{L}^{-1}$ IBA, distributed in a completely randomized design, with four replicates consisting in 20 cuttings per experimental unit, for a total of 560 cuttings per season of the year. The experiment was installed in the Forest Species Propagation Laboratory of Embrapa Florestas, in Colombo-PR.

Semihardwood cuttings were prepared with a length of $10-12 \mathrm{~cm}$, with a straight cut on top and a bevel cut on the base, maintaining two halved leaves in the apical portion. After disinfestation and treatments, cuttings were then planted into $53 \mathrm{~cm}^{3}$ polypropylene pots containing a 1:1 mixture of thin vermiculite grains and carbonized rice hulls, previously moistened.

After 120 days from installation of the experiment, which was conducted in a controlled temperature greenhouse with intermittent misting, the following variables were assessed: percentage of rooted cuttings, number of roots per cutting, length of the three longest roots per cutting $(\mathrm{cm})$, cuttings with callus, cuttings with new shoots and cuttings that maintained the initial leaves.

Variances of the treatments were tested for homogeneity with the Bartlett's test. Variables that shoved homogeneity were submitted to the analysis of variance and, when presented significant differences according to the test $\mathrm{F}$, their means were compared through the Tukey range test at $5 \%$ level of significance.

For all the considered variables, percentage of rooting, average number of roots per cutting, length of the three longest roots per cutting, percentage of cuttings with callus, cuttings with new shoots and percentage of the ones that maintained the initial leaves there was no interaction between the studied factors. There was a difference between the season of the year, for all the variables (Table 1).

The cuttings collected in winter presented the best rooting percentage $(46.96 \%)$ when compared with autumn $(25.71 \%)$, spring $(25.71 \%)$ and summer (14.82\%) (Table 1). Seasons of the year may interfere with the rooting rate since the nutritional and metabolic conditions of each species may change according to the environment.

According to TAIZ \& ZEIGER (2013), synthesis of auxins is greater in the apical meristems, and also in gems and young leaves. However, the season of the year where the best vegetative development of shoots was verified (summer), was also the one which presented the lowest rooting percentage (14.82\%) (Table 1).

The best results in number of roots per cuttings of Drimys brasiliensis were observed in winter with 4.24 (Table 1). This shows that in the season of the year where there was greater percentage of rooted cuttings, the roots system also was better developed. The number of roots per cutting is an important factor to be considered because seedlings with a better root development will have better chances of survival and a more vigorous and fast development, providing better fixation when planted in the field, which diminishes losses due to mortality (REIS et al., 2000).

Considering the length of roots per cutting, there was no significant difference between autumn, winter and spring, while the cuttings collected in the 
Table 1 - Comparison of means for semiharwood cuttings of Drimys brasiliensis Miers, rooted (RC), number of roots per cutting (NR), length of roots (MLR), cuttings with callus (CC), dead cuttings (DC), shoots cuttings (SC) and cuttings with initial leaves maintained (CLM), in the four seasons of the year, Curitiba (PR), 2013.

\begin{tabular}{lccccccc}
\hline Seasons of the year & RC \% & NR & MLR cm & CC \% & DC \% & SC \% & CLM \% \\
\hline Autumn & $25.71 \mathrm{~b}$ & $1.41 \mathrm{~b}$ & $0.22 \mathrm{a}$ & $10.53 \mathrm{c}$ & $53.75 \mathrm{a}$ & $45.53 \mathrm{~b}$ & $21.07 \mathrm{~b}$ \\
Winter & $46.96 \mathrm{a}$ & $4.24 \mathrm{a}$ & $0.29 \mathrm{a}$ & $35.17 \mathrm{a}$ & $11.07 \mathrm{~b}$ & $87.85 \mathrm{a}$ & $51.42 \mathrm{a}$ \\
Spring & $25.71 \mathrm{~b}$ & $1.41 \mathrm{~b}$ & $0.22 \mathrm{a}$ & $10.53 \mathrm{c}$ & $53.75 \mathrm{a}$ & $45.53 \mathrm{~b}$ & $21.07 \mathrm{~b}$ \\
Summer & $14.82 \mathrm{c}$ & $0.73 \mathrm{c}$ & $0.05 \mathrm{~b}$ & $20.89 \mathrm{~b}$ & $48.92 \mathrm{a}$ & $45.89 \mathrm{~b}$ & $41.78 \mathrm{a}$ \\
CV $(\%)$ & 43.93 & 47.56 & 69.73 & 52.69 & 30.83 & 23.17 & 42,87 \\
\hline
\end{tabular}

Means followed by the same letter in the column have no statistical difference at $5 \%$ level of significance.

summer presented lowest length with $0.05 \mathrm{~cm}$ (Table 1), due to the low percentage of rooting and therefore fewer roots per cutting.

Regarding the number of roots per cutting, winter also was the best season for the formation of cuttings with callus, presenting $35.17 \%$ (Table 1). For Drimys brasiliensis, the presence of this tissue with undifferentiated cells is a condition to further adventitious roots formation. This is related to the fact that in winter the rooting percentage (46.96\%) and the number of roots per cutting were gratest, giving as consequence a low mortality percentage $(11.07 \%)$, thus there was a low loss of cuttings in the production of seedling. These results showed best rooting indexes in the season where lower temperatures occurred, period in which the stock plant was probably in a dormant stage. According to CORRÊA \& FETT-NETO (2004), temperature may have influence over rooting, acting most of all on the absorption of nutrients and on metabolism, particularly in subtropical climate regions.

Rooting of cuttings collected in autumn, spring and summer was not viable for seedlings production of Drimys brasiliensis, because those seasons presented the highest mortality percentages (Table 1).

For the issue of new shoots, in Drimys brasiliensis it was observed that in winter the high percentage of new shoots issued $(87.85 \%)$ may have influenced on rooting, being the rooting percentage ofthis season of $46.96 \%$ and of cuttings with callus $35.17 \%$. According to HARTMANN et al. (2011), for some species the consumption of energies used to produce new shoots impairs the rooting process.

The highest percentages of cuttings that maintained their original leaves were found in winter $(51.42 \%)$ and summer $(41.78 \%)$ (Table 1$)$. The presence of leaves comes out to be an important rooting factor, and it is possible that the presence of leaves throughout the rooting process may contribute to a higher production of photoassimilate compounds, auxins and co-factors (NIENOW et al., 2010). However, in this research it was observed that the maintenance of leaves alone was not enough to increase rooting, because in summer, even with the high percentage of cuttings that maintained their leaves $(41.78 \%)$, there was a low rooting $(14.20 \%)$ (Table 1). This suggests that, for Drimys brasiliensis, good rooting is a result of an interaction between external and internal factors.

Concerning the different concentrations of IBA applied, there was no significant difference for any of the studied variables presenting an overall mean value of $28.30 \%$. Though, is possible to affirm that the use of IBA does not improve formation of roots in cuttings of Drimys brasiliensis in any season of the year.

Under the condition of the experiment here described it is possible to conclude that indolebutyric acid is not recommended for rooting of Drimys brasiliensis cuttings. Cuttings collected in winter were the ones that showed higher rooting percentage (46.96\%) for the production of nursery plant of Drimys brasiliensis.

\section{REFERENCES}

ABREU, D.C.A. et al. Caracterização morfológica de frutos e sementes de cataia (Drimys brasiliensis Miers - Winteraceae). Revista Brasileira de Sementes, Londrina, v.27, n.2, p.67-74, 2005. Available from: $<$ http://www.scielo.br/scielo.php?script=sci_artte xt\&pid=S0101-31222005000200010>. Accessed: Oct. 25, 2013. doi: $10.1590 / \mathrm{S} 0101-31222005000200010$.

CORRÊA, L.R.; FETT-NETO, A.G. Effects of temperature on adventitious root development in microcuttings of Eucaltptus saligna Smith and Eucaltptus globulus Labill. Journal of Thermal Biology, Grã-Bretanha, v.29, n.6, p.315-324, 2004.

CRONQUIST, A. An integrated system of classification of flowering plants. New York: Columbia University, 1981. 1262p.

FANTI, F.P. Aplicação de extratos de folhas e de tubérculos de Cyperus rotundus L. (Cyperaceae) e de auxinas sintéticas na estaquia caulinar de Duranta repens L. (Verbenaceae). 2008. 
58f. Dissertação (Mestrado em Botânica) - Setor de Ciências Biológicas, Universidade Federal do Paraná, PR.

HARTMANN, H.T. et al. Plant propagation: principles e practices. Boston: Prentice Hall, 2011. 915p.

NIENOW, A.A. et al. Enraizamento de estacas de quaresmeira em duas épocas e concentrações de ácido indolbutírico. Revista Brasileira de Agrociência, Pelotas, v.16, n.1-4, p.139-142, 2010.

NORBERTO, P.M. et al. Efeito da época de estaquia e do AIB no enraizamento de estacas de figueira (Ficus carica L.). Ciência Agrotécnica, Lavras, v.25, n.3, p.533-541, 2001.
REIS, J.M.R. et al. Efeito do estiolamento e do ácido indolbutírico no enraizamento de estacas do porta-enxerto Pyrus calleryana Dcne. Ciência Agrotécnica, Lavras, v.24, n.4, p.931-938, 2000.

SANTOS, C.M.G. etal. Substratos e regulador vegetal no enraizamento de estacas de pitaya. Revista Ciência Agronômica, Fortaleza, v.41, n.4, p.625-629, 2010. Available from: <http://www.scielo.br/ scielo.php?script $=$ sci arttext\&pid $=\mathrm{S} 1806-66902010000400016>$. Accessed: Nov. 15, 2013. doi: 10.1590/S1806-66902010000400016.

TAIZ, L.; ZEIGER, E. Fisiologia vegetal. Porto Alegre: Artmed, 2013. 954p

TRINTA, E.F.; SANTOS, E. Flora ilustrada catarinense. Itajaí: BR Petrobras, 1997. 19p. 